\title{
Challenges, Threats and Possibilities of National Education as a Driver for Innovative Development of Economy
}

\author{
Oksana Bondar-Pidhurska ${ }^{1, *}$, Alla Glebova ${ }^{2}$ and Yevheniia Solovykh ${ }^{3}$ \\ ${ }^{1}$ Higher Educational Institution of Ukoopspilka "Poltava University of Economics and Trade, Poltava, 36000, Ukraine \\ ${ }^{2}$ National University Yurii Kondratiuk Poltava Polytechnic, Poltava, 36000, Ukraine \\ ${ }^{3}$ V. N. Karazin Kharkiv National University, Kharkiv, 61000, Ukraine \\ *Corresponding authors. Email: bondarpodgurskaa@gmail.com
}

\begin{abstract}
The study aimed to substantiate the place and role of national education as a driver of innovative economic development, generalization of challenges, threats and opportunities for its development. At the same time, education as a subsystem of knowledge is included by us in the index of innovative development and the modified index of human development, which is calculated by the method of basic components and a sliding matrix in the form of a supplement. The downward trend in these indicators in Ukraine during 2007-2017 indicates negative processes in the national economy due to the low level of knowledge capitalization and the growing number of challenges and threats to national education. This reduces the level of satisfaction of vital interests of the population, worsens its quality of life and raises the question of new approaches to education management with an emphasis on building an innovative model of economic development. "Capitalization of knowledge" is positioned as a marker of the effectiveness of education in an innovative economy. In order to confront new threats and challenges to national education, its main opportunities have been identified, which will allow to form the key competencies of a modern European-style specialist and increase the level of knowledge capitalization. Among the opportunities of national education as a driver of innovative economic development are: online education, smart education, adult education, internationalization of educational space, creating space for creativity and innovation, increasing mobility of participants, expanding new forms of learning (distance, network), competence learning.
\end{abstract}

Keywords: challenges, threats, opportunities, education, driver, innovative development of economy

\section{INTRODUCTION}

In the context of globalization and increasing competition, education plays a strategic role at the present stage, which not only allows to acquire the accumulated knowledge, but also to create the appropriate conditions and new technologies for the future national economy.

Due to the theory of human capital, education in many countries has been regarded as one of the main sources of economic growth, as a tool to mitigate social inequality and as a means of combating unemployment $[1$, p. 22]. It should be noted that human capital in the national wealth of the world community is $64 \%$, natural capital $-20 \%$, and physical only $16 \%$. The share of human capital in developed countries (Finland, Switzerland, Germany, Japan and USA) is $80 \%$ of their national wealth [2]. And the main growth of this is provided by education.

\section{LITERATURE REVIEW AND PROBLEM STATEMENT}

\footnotetext{
A significant role of education is confirmed by a number of national and international legal acts. In particular, the right to education is an internationally recognized human right. For the first time, the question of a citizen's right to education was formally enshrined in the Declaration of Independence of the United States of America (1776) and the United States Constitution (1787 p.). Later, the right to education was proclaimed in the Universal Declaration of Human Rights (Article 26) and in the International Covenant on Economic, Social and Cultural Rights [3, p.15]. In this case, education is now turning into a driver of the modernization processes of all forms and types: production, society, economy as a whole [4].

Thus, in the context of decentralization, education becomes a center of creative ideas, creating an ecological environment, innovation centers in the regions, which usually contributes not only to the development of human potential in increasing the number of cities, but also
} 
improving living standards [5].In a competitive environment, education provides the formation of such an important resource as intellectual capital, which is a strategic resource of modern complex socio-economic systems, which allows you to use the experience and knowledge in the field of production and consumption.

This approach demonstrates that competitive education becomes a tool that forms a value chain (according to $\mathrm{M}$. Porter, 1998); allows you to compete not only in the national but also in the international market; affects the increase of labor productivity; creates knowledge as a resource not limited by space and time; allows you to turn knowledge into a product that can be sold, distributed, exchanged; provides integration of science, production and services; notes the inseparability of knowledge from its carrier, namely human capital, which is part of the market valuation of a modern enterprise; allows to produce hightech services and related to human development (biophysical, intellectual, cultural, social) [2].

Thus, the purpose of this research will be to substantiate the place, role and problems of national education as a driver of innovative economic development, to summarize the challenges, threats and opportunities for its development.

To ensure sustainable innovative economic development and a high level of knowledge capitalization, it is necessary to focus on the effective use of intellectual capital (ie intangible assets or knowledge), which significantly increases the market value of the enterprise, its investment and innovation attractiveness, competitiveness in different markets

It should be noted that Professor V.P. Barancheev [6] identifies intellectual capital with intangible assets, which he organized in the form of a pyramid, which was based on authoritative assets (names, brands - brands, authority, etc.) and above human resources, skills, abilities employees (Fig. 1).

Because in the XXI century education is a producer of intangible assets, intellectual capital, knowledge, skills and abilities, the development of national innovation systems is seen as a process of complex transformations aimed at intensifying innovation processes on a systematic basis with the best educational standards. will ensure a sustainable pace of socio-economic development and improving living standards.

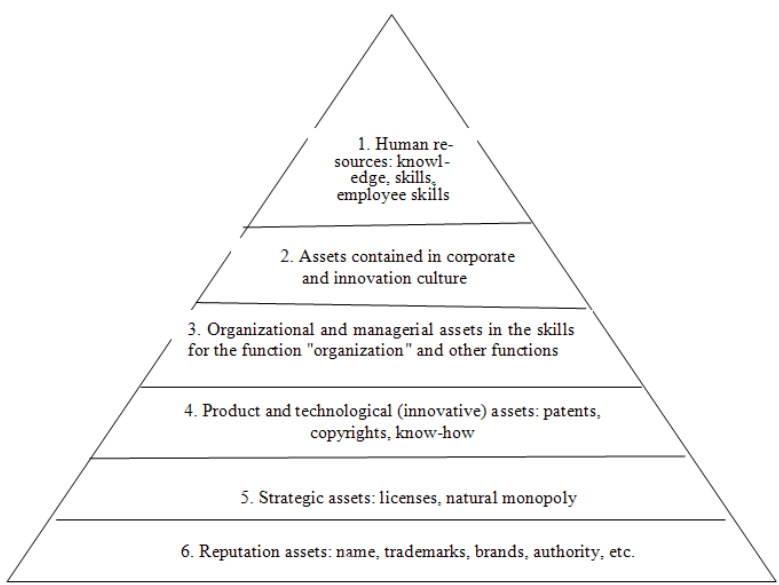

Figure 1. Pyramid of intangible assets (intellectual capital), proposed by Professor V.P. Barancheev Source: adapted by the authors based on processing the source [6]

This is stated in the work of AA Kasich (2013) [7]. At the same time, the authors' works do not single out the capitalization of knowledge as the main problem of innovative economic development today.

\section{METHODS}

The research methods will be analysis and synthesis, induction and subtraction, cause and effect analysis, the main components method and a sliding matrix for calculating the modified indicator of the human development and innovation development index, and others.

\subsection{Data Analysis}

During the formation of the data set for the calculation of the innovation development index of Ukraine 2007-2017, which is a set of three subsystems "knowledge", "innovation", "investment", the triangle of competitiveness of the national economy was formed [8]

The analysis of the data of the subsystem "Knowledge" allowed to state the decrease of the share of patents for inventions of Ukraine by $18,71 \%$ among the countries of the world and decrease of the share of performed scientific and scientific works and technical works in GDP by $0,29 \%$. This is a negative trend in the development of the knowledge economy in 2007-2017, which is partly caused by a decrease in the percentage of scientists from the total number of employees by $0.12 \%$. This is evident from the results of causal and consequential analysis.

The results of the analysis of the data of the subsystem "Innovation" made it possible to distinguish the tendency of reduction of the share of realized innovative products in the volume of industrial by $6 \%$, and the introduction of new technological processes at the rate of 1 scientist by 36 units per person, while increasing the share of enterprises introducing $2,8 \%$ in 2017 compared to 2007. This 
characterizes the government's understanding of the role of innovation in the growth of an economy that claims to be innovative. Analysis of the data of the subsystem "Investments" showed that the share of the state in financing the innovation activity of industrial enterprises increased by $1.15 \%$ in 2017 compared to 2007, but this was not enough to generate a positive trend in the share of GDP in research, which in the reporting year decreased by $0.45 \%$ compared to the base year 2007.

The index of innovative development was calculated by the method of principal components and the sliding matrix in the additive form, which, due to negative tendencies in the "knowledge" plane, decreased by 1.73 times (Fig. 2.) [8]. The results of the analysis allowed us to state that the largest share falls on the share of sold innovative products in the volume of industrial products $(\%)$. At the same time, given its downward trend, with the increase in the share of enterprises implementing innovations in 2017 by $2.8 \%$ compared to 2007 , the problem of commercialization of scientific and technical results and commercialization of knowledge becomes obvious.

At the same time, the tendency of constant decrease in the rate of modified human development in 2007-20017 by $53.47 \%$ (2.15 times or 0.385$)$ indicates ineffective state regulation of crisis situations: a country from the group of a high level of human development joined the low group. The dynamics of the Innovation Index of Ukraine in 2007-2017 indicates a downward trend in the reporting year 2017 by 0.335166 compared to the base year 2007 (1.73 times). This negatively affected the level of satisfaction of vital interests of the population due to low capitalization of knowledge. The dynamics of changes in the modified indicator of human development and the index of innovative development of Ukraine in 2007-2017 is presented in Fig. 2.

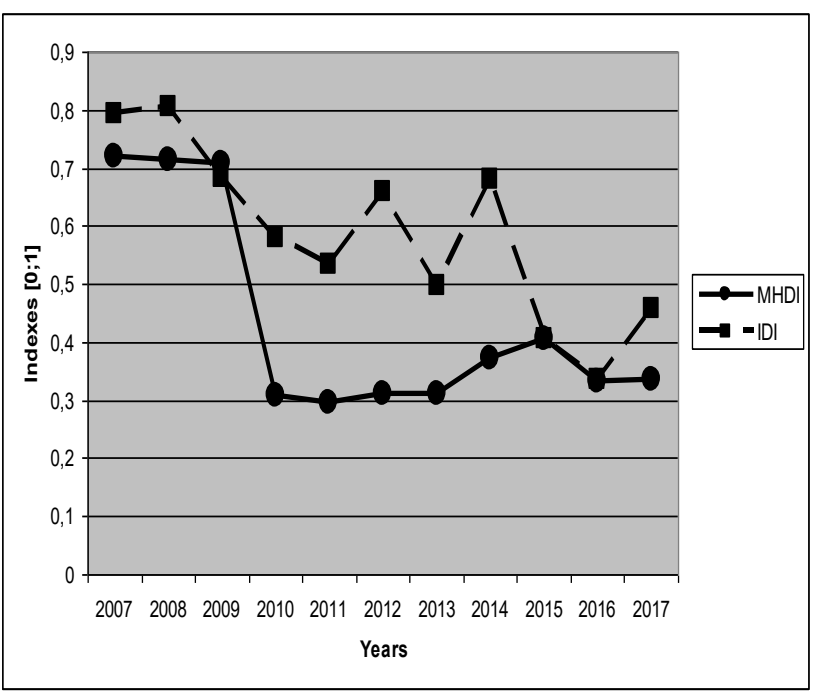

Figure 2. Dynamics of change of the modified index of human development and innovative development index of Ukraine during 2007-2017

\section{Conditional designations:}

The following groups of indicators were used to calculate the Modified Human Development Index (MHDI): X11$\mathrm{X} 20$ - indicators of the social subsystem MHDI, in particular X11 - life expectancy (at birth), years; X12 - the average length of training, years; X13 - GNI per capita, USD US PPP, current prices; X14 - Fertility coefficient (total fertility rate), \% - strike; X15 - the number of suicides per 100 thousand people (mortality from intentional self-harm); X16 - change in population, \%; X17 - level of satisfaction with the life of the population, points; X18 - average living conditions per inhabitant, m2; X19 - social security indexes (ratio of the average size of the assigned monthly pension to pensioners who are registered with the Pension Fund bodies (UAH) to the subsistence minimum by the end of the year (UAH)); X10 - indicator of inequality in the distribution of available resources (Gini index).

X21-X29 - indicators of the economic subsystem MHDI: X21 - Internet usage level,\% of population; X22 unemployment rate, $\%$ X23 - labor productivity, mln. USD per thousand employed persons; X24 - degree of depreciation of fixed assets, \%; X25 - \% of GDP on R \& D; X26 - inflation,\%; X27 - import coverage indicator,\%; X28 - taking into account public external debt (\% of GDP); X29 - the level of the shadow economy in\% of the official GDP

X31-X34 - components of the environmental subsystem of MHDI: X31 - energy intensity of GDP in the PPP 2015 ( $\mathrm{kg} \mathrm{NU} \mathrm{/} \mathrm{\$ );} \mathrm{X32} \mathrm{-} \mathrm{indicators} \mathrm{of} \mathrm{the} \mathrm{state} \mathrm{of} \mathrm{the}$ environment environment in the light of global warming of the climate (CO2, $\mathrm{kg}$ / person); X33 - formation of waste per person, thousand tons; X34 - consumed fresh water per person2, mln.m3.

The following indicators have grown significantly during the calculation of the Innovation Development Index (IDI): $\mathrm{X} 1$ - the share of patents for inventions in Ukraine among the countries of the world (\%); X2 - the percentage of scientists from the total number of employees (\%), \%; X3 the share of volume of scientific and scientific work performed work in GDP (\%); X4 - share of enterprises that implemented innovations (\%), \%; X5 - share of implemented innovative products in the volume of industrial (\%), \%; X6 - introduced new technological processes per 1 scientist, units per person; X7 - state share in finance Innovation activity of industrial enterprises (\%); $\mathrm{X} 8-\%$ of GDP for R\&D [8].

Source: Created by the authors based on data of the State Statistics Service of Ukraine and its own calculations using the Microsoft Excel software package.

Thus, the decrease in the level of the modified human development index and the index of innovative development of Ukraine during 2007-2017 indicates negative processes in the national economy, reduced satisfaction of vital interests of the population, deterioration of its quality of life, low capitalization of knowledge in society. This raises the question of new approaches to education management with an emphasis on building an innovative model of economic development. Therefore, during the approval of the innovative model of 
Ukraine's development a new model of human resources development should be formed, based on the focus on highly skilled labor, continuity of the process of enrichment of knowledge and professional development, creative thinking, scientific organization of labor and more. The attitude to the tasks of modern education must also change radically in the direction of increasing the level of knowledge capitalization.

\subsection{Analysis of competency education in the context of increasing the level of knowledge capitalization}

Studies of trends in the development of education in the world testify to the widespread introduction in the pedagogical practice of different foreign countries competently oriented education, which facilitates the acquisition of vital (key) competencies for students. Also important is the process of developing monitoring procedures to track learning outcomes and measure students' competencies across different educational sectors. This makes it possible to evaluate the effectiveness of education, its relevance to the current needs of the labor markets and society.

Particularly noteworthy is the need for deep fundamental research into the very nature of competently oriented education. So, the concept of "competent education" originated in the United States in the process of studying the experience of distinguished teachers. It is based on practical best practice and has been the result of numerous attempts to analyze it, having developed some theoretical, conceptual framework.

The concept of "competence" Ukrainian education operates in the meaning offered by European countries. Experts initiated in 1997 within the Federal Statistical Department of Switzerland and the National Center for Educational Statistics of the USA and Canada, the DeSeco Program ("Defining and Selecting Competencies: Theoretical and Conceptual Foundations") define the notion of competence (smpetency) as the ability to successfully satisfy individual, individual, and social needs. and complete the tasks.

Competence is based on knowledge and skills, but they are not exhausted, necessarily encompassing a person's attitude to them, and her experience, which enables this knowledge to "weave" into what she already knew and her ability to comprehend a life situation in which she can apply them. Thus, each competence is built on a combination of cognitive attitudes and practical skills, knowledge and skills, values, emotions, behavioral components, that is, all that can be mobilized for active action.

In the late 80 's - early 90's of XX century, there was an attempt to define competence as a certain educational result. Today, despite some differences in approach, US experts identify three major components in competency education: it is the formation of knowledge, skills and values of the individual.

Considering the national cultural values and the specificity of the period of formation of the national innovation system, in our opinion, it is advisable to present the main components (subsystems) of higher education in higher education institutions as a set of three subsystems during the approval of the innovative development model of economy (Fig. 3).

Therefore, today the competence approach is one of those that contribute to the modernization of the content of education through the formation of competitive skills and knowledge of the specialist. It complements a number of educational innovations and classical approaches that help teachers to harmoniously combine positive experiences to form new professionals in higher education and general life goals in general.

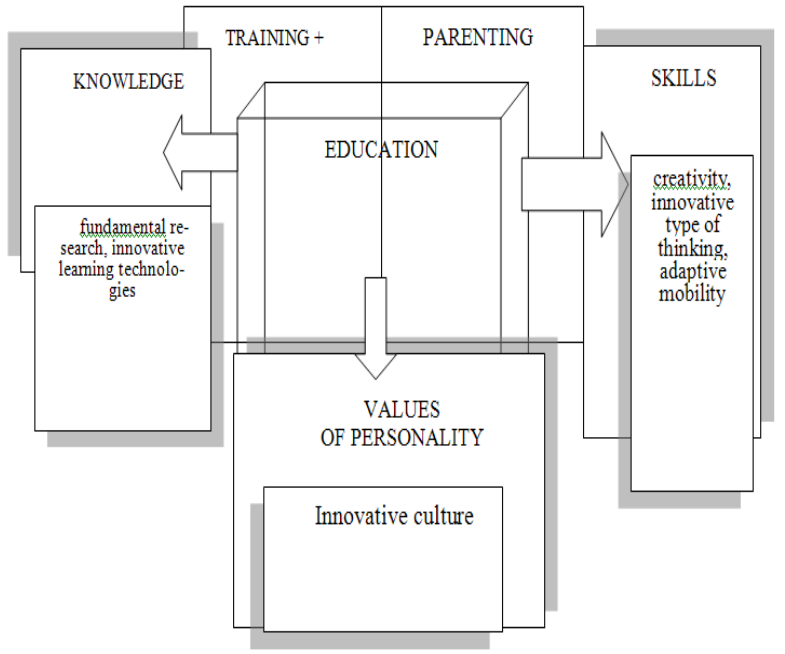

Figure 3. The main components (subsystems) of competent education for universities in the period of approval of the innovative development model of economy

Source: built by the authors.

At the same time, the role and importance of the concept of "Lifelong Learning" is growing, which improves not only professional life but also personal life.

Awareness of the importance of lifelong learning for human development led in 2000 to the adoption of the Memorandum on Lifelong Learning, which emphasized its importance for the process of creating national wealth.

Along with this, the positioning of education as a driver of innovative economic development of Ukraine in the XXI century should involve the formation of key European competencies of the modern specialist (specialist of the European model). Such a specialist must be able to withstand the main challenges and threats, as well as use all opportunities to develop education and increase the level of knowledge capitalization (Fig. 4). 


\section{FINDINGS}

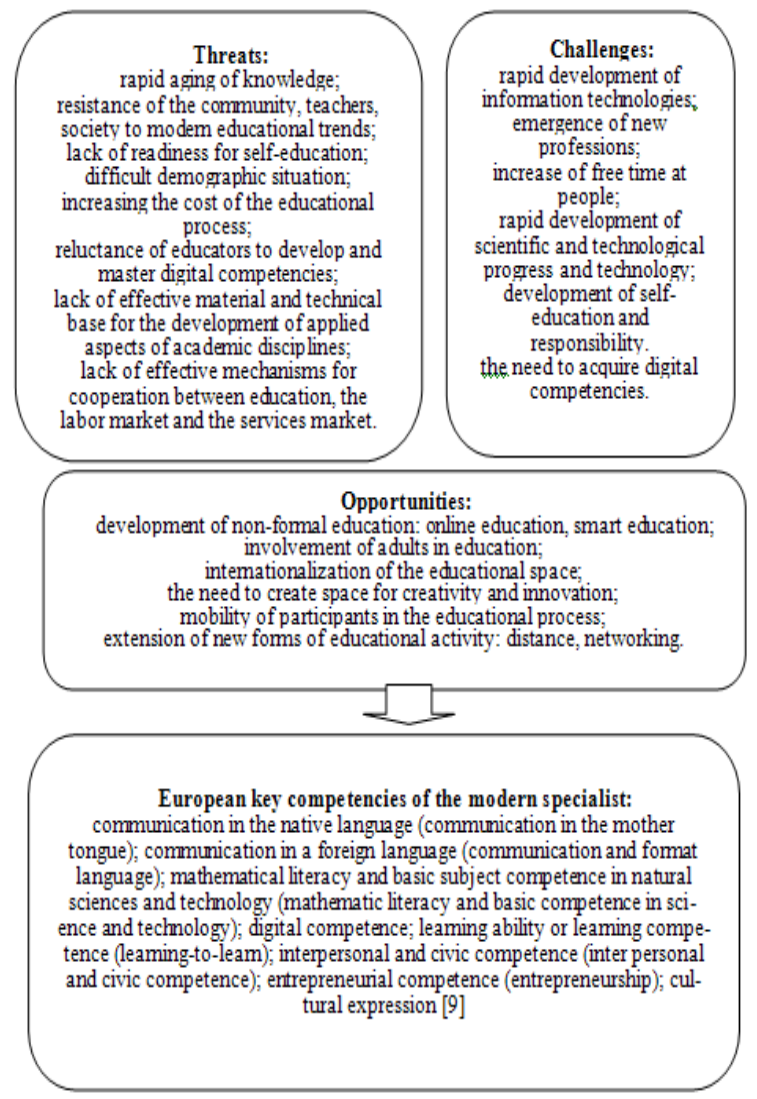

Figure 4. Generalization of challenges, threats and opportunities for the development of education in the format of formation of key competencies of a modern specialist of European level Source: built by the authors

\section{CONCLUSIONS}

The strategic role of education as a driver of the national economy, a producer of intangible assets, a center for creating creative ideas, one of the main sources of economic growth and improving living standards is substantiated.

From the point of view of education as a driver of innovative economy, the index of innovative development of Ukraine's economy was calculated in the format of three subsystems (knowledge of innovation, investment), which in 2007-2017 decreased by 1.73 times. To assess the standard of living of the population, a modified Index of Human Development of Ukraine 2007-2017 was calculated, as well as a tendency to reduce it by 2.15 times for all its components (economic, social and environmental).

The capitalization of knowledge as the main problem of education and innovative economic development of
Ukraine in 2007-2017 is highlighted. In order to increase the level of capitalization of knowledge, the main components (subsystems) of competence education in higher education institutions during the implementation of an innovative model of economic development: knowledge, skills and personal values (innovation culture). Threats, challenges and opportunities for the development of national education in the format of formation of key competencies for a specialist of European level are summarized. Emphasis is placed on the development of national education in the form of: online education, smart education, adult education, internationalization of educational space and creating space for creativity and innovation, enhancing the mobility of participants in the educational process, expanding new forms of learning (distance, network).

\section{REFERENCES}

[1] Garashchuk, O. Socio-economic aspects of higher education development in Ukraine: diss. Ph.D. in Economics: NAN Ukraine, Council for the Study of Productive Forces of Ukraine (2007)

[2] Karpenko, M.M. Education during life as a factor of human development. Analytical note. Humanitarian Development Series. 20. https://niss.gov.ua/ doslidzhennya/gumanitarniy-rozvitok/osvitaprotyagom-zhittya-yak-chinnik-lyudskogo-rozvitku (2015). Accessed 27 Mar 2019

[3] Lopushniak, G, Rybchanska, H. Higher education in Ukraine: state regulation and development prospects. Lviv, Liga press (2018).

[4] Kasych, A., Vochozka, M. Modernization processes in the modern world: methodology, evolution, tendencies. Revista ESPACIOS. 40 (24), https://www.revistaespacios.com/a19v40n24/19402420. html (2019). Accessed 30 Mar (2019)

[5] Kasych, A.O. Theoretical Aspects of the Impact of Decentralization Processes on the Economic Development of the Country Actual Problems of Economy. 8, 16-21 (2016)

[6] Barancheev, V.P. Knowledge management. Moscow, Center for Marketing Research and Management (2005).

[7] Kasych, A.O. The experience of national innovation systems' formation in developing countries. Actual Problems of Economics. 5 (143), 46-49 (2013) 